\title{
Vernacular Knowledge, Natural Disasters, and Climate Change in Monsoon Asia
}

\author{
Senjo Nakai \\ https://orcid.org/0000-0002-1273-6379 \\ Thammasat University, Thailand
}

\begin{abstract}
In Monsoon Asia, home to more than half of the world's population, extreme climatic events are expected to become more frequent and intense due to climate change. Modern disaster management to date has focused on assessing the risks of natural hazards based on historical data, responding to disasters through prevention and mitigation techniques, and information campaigns, instead of vernacular knowledge cultivated in the local environment. This has led the public to a dangerous complacency about the power of technology over nature, and neglecting the possibility of "unforeseen" events. Climate change has not only made it more difficult to assess the risks of natural hazards, but has also diminished local resilience to them. However, since the adoption of the Hyogo Framework for Action in 2005, Monsoon Asia has begun multi-sectoral efforts to build local resilience to natural hazards by integrating vernacular knowledge into modern disaster management. Whereas in the past, experts and government agencies regarded the public as mere recipients of their services, they have now become acutely aware of the need to build partnerships with local communities to compensate for current technological limitations in disaster management, and to imaginatively prepare for the increasing risks of climatic contingencies. To achieve these goals, vernacular knowledge can be a useful resource, and a number of efforts have been initiated in the region to preserve such knowledge in imaginative forms to pass it on to future generations.
\end{abstract}

Keywords: vernacular knowledge, Monsoon Asia, natural disaster management, climate change, extreme climate, natural hazards

eTropic: electronic journal of studies in the tropics publishes new research from arts, humanities, social sciences and allied fields on the variety and interrelatedness of nature, culture, and society in the tropics. Published by James Cook University, a leading research institution on critical issues facing the world's Tropics. Free open access, Scopus Listed, Scimago Q1. Indexed in: Google Scholar, DOAJ, Crossref, Ulrich's, SHERPA/RoMEO, Pandora. ISSN 1448-2940. Creative Commons CC BY 4.0 free to download, save and reproduce. To cite, include: Author(s), Title of Paper, Editors (Eds.) Special Issue Title (Special Issue) eTropic, volume, issue, year, pages and DOI: http://dx.doi.org/10.25120/etropic.20.2.2021.3810 


\section{Introduction: Enter Monsoon Asia}

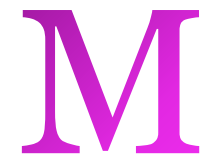

onsoon Asia is a cradle of ancient civilisations and is still home to $52.9 \%$ of the world's population (Kyuma, 2009, p.1). The reversal of the direction of monsoon winds between the wet and dry seasons has led to the formation of a diverse cultural and ecological environment in this region. Concomitantly, the region has been exposed to a constant risk of natural hazards. In recent years, largescale disasters have occurred in the region that have exceeded the estimations of scientists, raising concerns about the effects of climate change. Low-lying cities and coastal towns, especially those with high concentrations of population and major industries, are expected to be more vulnerable to natural hazards, such as rising sea levels, droughts, tropical storms, and floods (Shrestha, 2014; Asian Development Bank, 2015) [see Figure 1]. It has become increasingly clear that modern science and technology alone will not be able to cope with the impacts of climate change.

Figure 1. North Okkalapa, Yangon, damaged by Cyclone Nargis, early May 2008.

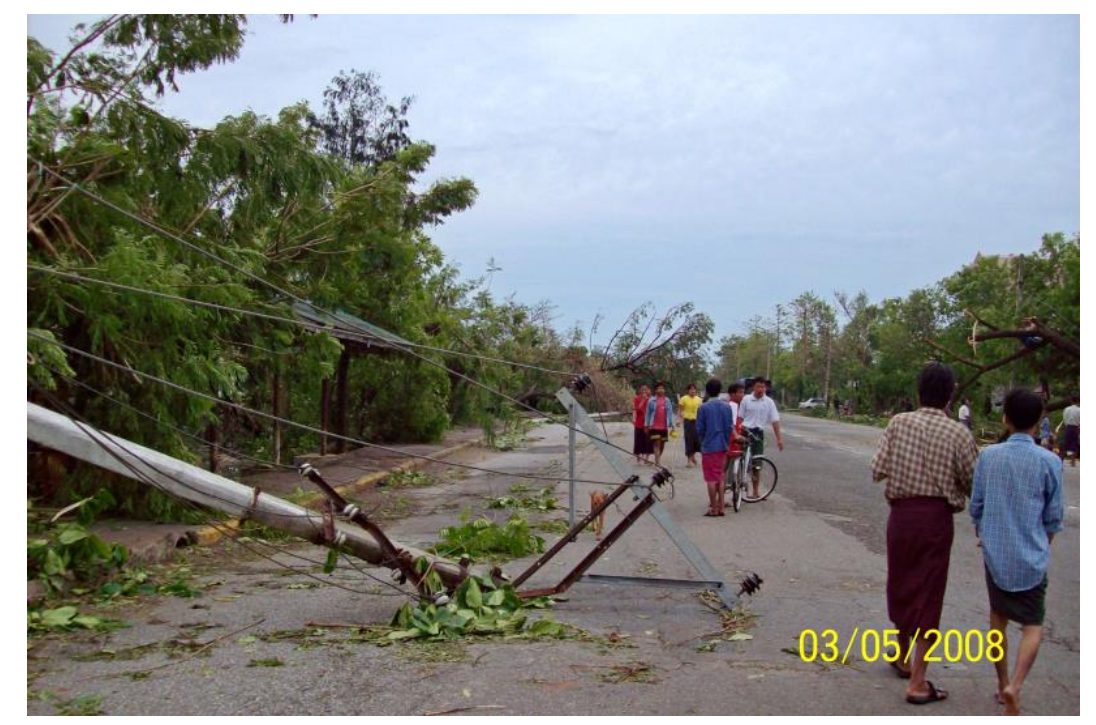

Cyclone Nargis was the deadliest natural disaster in Myanmar's history, with 84,500 confirmed dead and 53,800 missing (Association of Southeast Asian Nations et al., 2008, p. 1). The Ayeyarwady Delta, a densely populated area known as the rice bowl of Myanmar, was devastated by this unseasonal cyclone, which caused devastating storm surge damage. (Photo: Thien Thien Win, 2008).

Despite the increasing risk of extreme weather events, people are still struggling to come to terms with the multifaceted phenomenon of climate change. At the same time, rapid progress in modern disaster management has given people a false sense of security about their safety, and the effectiveness of modern disaster management. 
eTropic 20.2 (2021) Special Issue: Tropical Imaginaries and Climate Crisis

In this respect, it is important to remember that just less than a century ago, the peoples of Monsoon Asia still protected their lives and property from natural hazards without relying on modern science and technology. They had effectively and imaginatively sublimated their experiences of natural disasters into vernacular knowledge with reference to local culture through collective memories, beliefs, artefacts, and customs (Sasamoto, 1994). Such knowledge, while not readily compatible with scientific discourse, is by no means at odds with it. With ingenuity, vernacular knowledge can be a valuable medium for people to understand and cope with such multifaceted phenomena as climate change.

This article aims to explore the utilization of vernacular knowledge to help Monsoon Asian societies recognize the growing risk of extreme events, and prepare for climate change contingencies. The article commences by addressing the structural problems of modern disaster management, and why unforeseen events continue to occur despite concerted efforts by government agencies and scientists. This is followed with examples of vernacular knowledge of natural disasters in the region, and how they have been integrated into modern disaster prevention and mitigation initiatives through imaginative preservation activities and education. The article is furthermore supplemented with photographs and annotations to help assemble the fragmented images of natural disasters and local initiatives into a more coherent social imaginary of climate change, challenges, and local responses.

Although Monsoon Asia is a vast region spanning countries in South, Southeast, and East Asia, this article will focus on case studies from Japan, Thailand and Indonesia, along with supplementary examples from Myanmar, Vietnam, and Papua New Guinea. These countries, which have all experienced devastating natural disasters over the past two decades, aptly illustrate a renewed interest in vernacular knowledge to improve local resilience to natural disasters. To identify common problems in modern disaster management, this article will also examine incidents of earthquakes and tsunamis that have struck the region, and furthermore present recent research on the potential impacts of climate change on earthquakes and tsunamis.

\section{Vernacular Knowledge of Natural Disasters in Monsoon Asia}

Monsoons have shaped the climate of South Asia, Southeast Asia, and parts of East Asia. In South and Southeast Asia, moist, northward winds blow from the oceans in summer, bringing a rainy season, while southward winds blow from the Tibetan Plateau in winter, bringing a dry season. This unique climate has had a profound impact on the topography of the region, and the lives of its inhabitants. Vast alluvial lowlands were formed in the middle and lower reaches of major rivers flowing out from the Himalayas and Tibetan plateau, and rice paddies have developed as an adaptive 
eTropic 20.2 (2021) Special Issue: Tropical Imaginaries and Climate Crisis

agriculture to the heavy rainfall and flood plains during the rainy season. As a result, the region produces $87.5 \%$ of the world's rice (Kyuma, 2009, pp. 2-3). However, the intensity of the monsoon has changed drastically over the last few decades, which is believed to be linked with climate change.

\section{Monsoon Asia}

The term Monsoon Asia was introduced by western and Japanese geographers and ethnographers, such as Jules Sion and George Cœdès, in the 1920s after the introduction of meteorology and the colonization of Asia. Later, it evolved to refer not only to a geographical and climatic region, but also to the cultural continuity among Asian countries.

The concept of Monsoon Asia took a different turn in Japan, which was at one time under the threat of colonisation by Western powers, and later became a coloniser itself. This is well illustrated in the concept of füdo, or "climate and culture," proposed by Tetsurō Watsuji. Though a critique of Heidegger's temporality-oriented existentialism, Watsuji developed the idea of monsoon type civilization based on a common orientation towards the natural environment among inhabitants of Asian countries, including Japan. In his Fūdo: Ningengakuteki kōsatsu ( $A$ Climate: $A$ Philosophical Study) (1935/1962), he claimed that the monsoon was both a source of fertility, and a cause of destruction, and that the people of Asia had been developing an amiable attitude towards nature (pp. 19-20). He also believed that the characteristics of the monsoon type led to the formation of an ineffective political and economic system in the region, and eventual colonization. In the interwar period, Watsuji's ideas were used to justify the expansion of militarist Japan into Asia under the banner of Pan-Asianism (lizuka 1942, quoted in Okada 1985, p. 391). Although the concept of füdo came under heavy scrutiny after the war for its reductionist tendency and association with wartime colonialism, the interest in the intricate relationship between Asian cultures and the environment continued in Tadao Umesao's ecological theory of civilisation (1957) and Heita Kawakatsu's maritime history of civilisation (1997).

Outside of Japanese academic circles, the concept of Monsoon Asia, despite being criticised in the post-war period and shunned in the 1980s, has recently experienced a resurgence in the fields of geography and climatology due to the intensification of anthropogenic climate change. The drastic increase in vulnerability to climate change has been recognised as a regional concern, and in the humanities, the concept has re-emerged as an imaginative way to conceptualise and share local and geographical knowledge of the impacts of climate change (Amrith, 2018, p. 173). 
eTropic 20.2 (2021) Special Issue: Tropical Imaginaries and Climate Crisis

Climatologists predict that global warming of the atmosphere and oceans will increase the frequency and intensity of oceanic-atmospheric phenomena (Oppenheimer et al., 2019). Around tropical and subtropical regions, including Monsoon Asia, there will be significant changes in weather patterns, sea level rise is expected to be higher than the global average, and the intensity of tropical storms is expected to increase. In Monsoon Asia, droughts and floods will occur more frequently due to the effects of the Indian Ocean Dipole and the El Niño-Southern Oscillation (Azzali et al. 2021, p.6; IPCC, 2021).

Recent studies also indicate a possible link between climate change and crustal increase in the Monsoon Asian region. It is postulated that the strength of the Asian monsoon is correlated with the uplift of the Himalayas and Tibetan Plateau, the evolution of gateways, and the retreat of shallow sea in Central Asia (see Clift, Tada \& Zheng, 2010). Some researchers postulate that as glaciers recede and erosion rates increase in the Himalayas and Tibetan plateau, the resulting changes in stress on faults will increase earthquakes (Usman, 2016; Mishra, 2021).

\section{Vernacular Knowledge}

The term Monsoon Asia also refers to the civilisations and vernacular knowledge that have been cultivated within the region's unique habitats. In disaster-prone areas, it has been passed on as a valuable medium for the inhabitants to preserve cultural memories of past disasters and survival skills to future generations (Sasamoto, 1994, p. 69).

Vernacular knowledge can be in either tangible forms (e.g., farming tools, monuments, architecture, costumes, and visual art) or intangible forms (e.g., proverbs, beliefs, performing arts, customs, and place names) although the two often overlap. The tangible forms include reinforced natural levees in the lowlands of the Red River basin in Vietnam (Okae, 2019) [see Figure 2] and wajū, circular embankments on the flood plains that protected fields and settlements in Japan (Itō, 2010) [see Figure 3]. These levees and embankments have protected communities from floods and storm surges for centuries. Intangible forms include the legend of the Yonok kingdom, which is still remembered by the people in the Wiangnonglom Wetlands in Upper Northern Thailand, a region prone to a variety of natural disasters (Nakai, 2017). According to a local chronicle (Praya Prachakitkorachak, 2014, p.197), this city-state is believed to have flourished until around 460 CE (Nithi, 1970, cited in Ongsakul, 2005, p. 19). After the people ate a giant albino eel, the kingdom and the people disappeared into the depths of the water, except for one widow who did not eat the eel [see Figure 4]. A similar myth of an eel kept by a widow which causes the land to be engulfed by (sea) water was recorded in the village of Lamalera in eastern Indonesia - a region known 
eTropic 20.2 (2021) Special Issue: Tropical Imaginaries and Climate Crisis

for natural disasters, especially earthquakes and tsunamis (see Lundberg, 2003, pp. 78-79).

The term vernacular knowledge is sometimes used interchangeably with folklore or indigenous knowledge. Both of the latter terms, however, imply that the knowledge is passed on orally within a relatively small traditional community. However, as many researchers have observed, nowadays it can be transmitted outside the boundary of the traditional community through media (Rahman et al., 2017; Sato et al., 2017). Therefore, in this study, the term vernacular was chosen to highlight this change in knowledge dispersal in the modern era.

Vernacular knowledge also helps the local community to comprehend complex and sometimes abstract phenomena - such as climate change. Anita Lundberg (2021) examines how environmental and climate crises faced by local communities in Bali have been represented in graffiti wall art. She points out that the popular representation of Bali as a tropical island paradise is subverted by the symbolic image of a traditional dancer wearing a gas mask. The dancer is positioned in various art scenes, including posing with fish filled with plastic, and poised within a landscape of coal-fired power plants - signifying a major contributor to global warming.

Figure 2. Traditional levee and farmer tending paddy, Vietnam's Red River Delta.

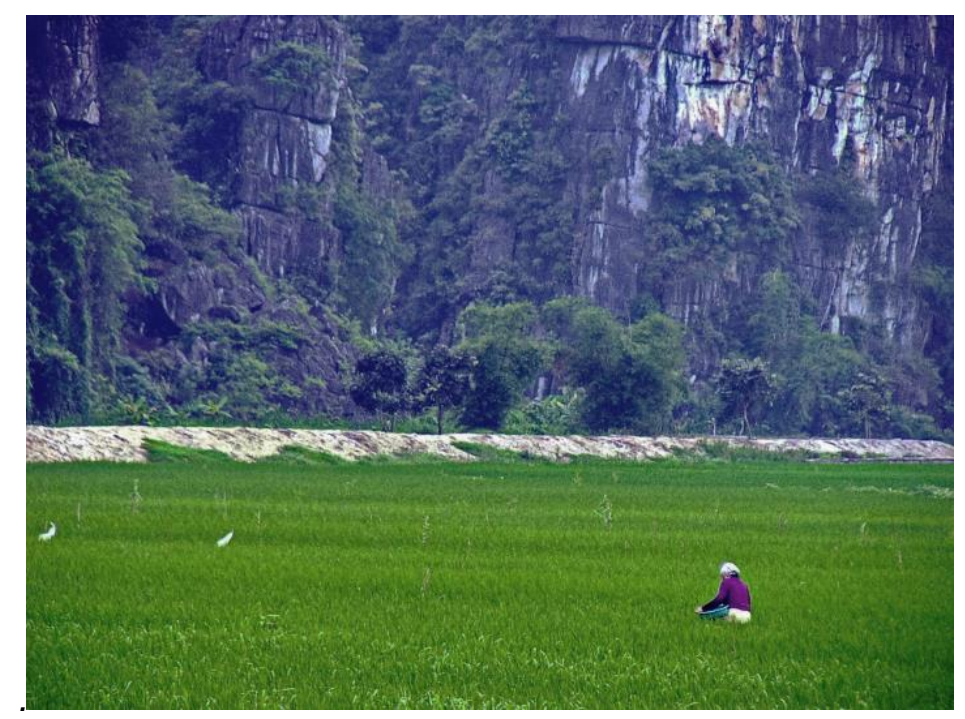

The Red River Delta, formed at the mouth of the river and its tributaries, is the most densely populated region in Vietnam (21.1 million people), and the second largest riceproducing region (15.2\% of the total rice producing area) (Okae, 2019, pp. 3, 9). Autonomous local organizations have developed to manage infrastructure and water resources in this delta (Haruyama, 2000, p. 921; Luong, 2017). It is not a coincident that Hoa Lư in Ninh Binh province, pictured here, was home to the first Vietnamese kingdom of Đại Cồ Việt at the end of the 10th century. (Photo: Nakai, 2012). 
eTropic 20.2 (2021) Special Issue: Tropical Imaginaries and Climate Crisis

Figure 3. Aerial view of Wajū in Kisosaki Town, Mie Prefecture

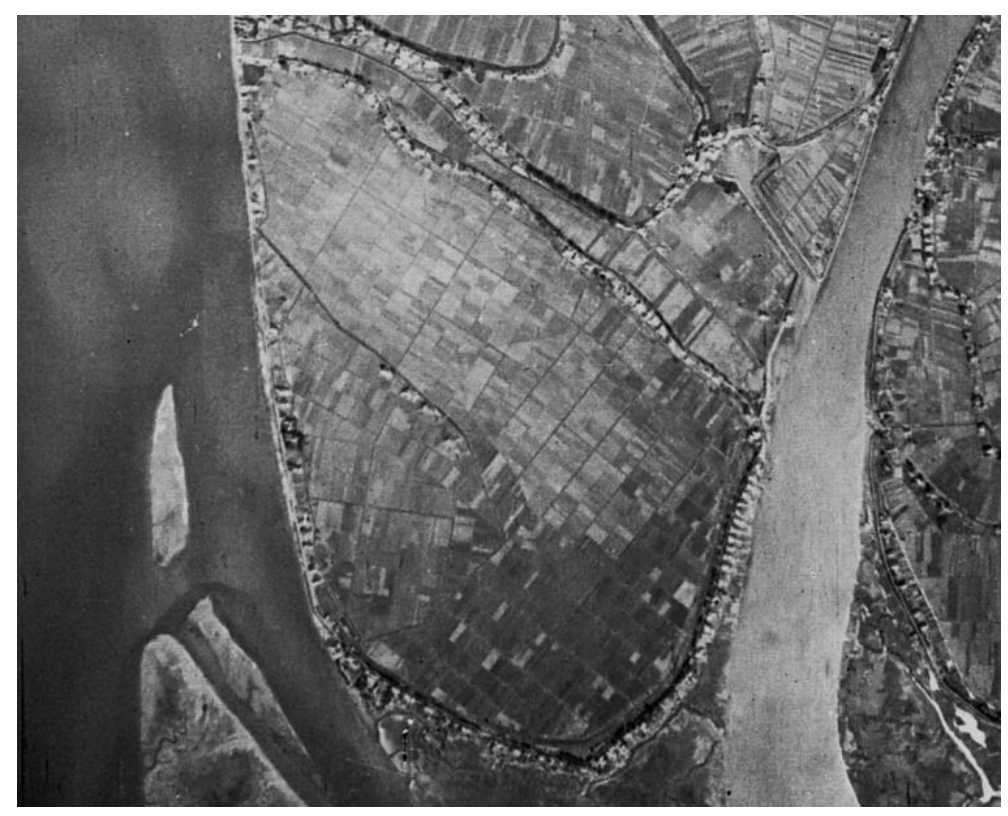

In the centre of the image is a river island bounded by the Genroku wajū. Reproduced with permission from the Geospatial Information Authority of Japan, 1945, from https://mapps.gsi.go.jp/maplibSearch.do?specificationld=743869.

Figure 4. Temple mural illustrating the destruction of the legendary kingdom of Yonok.

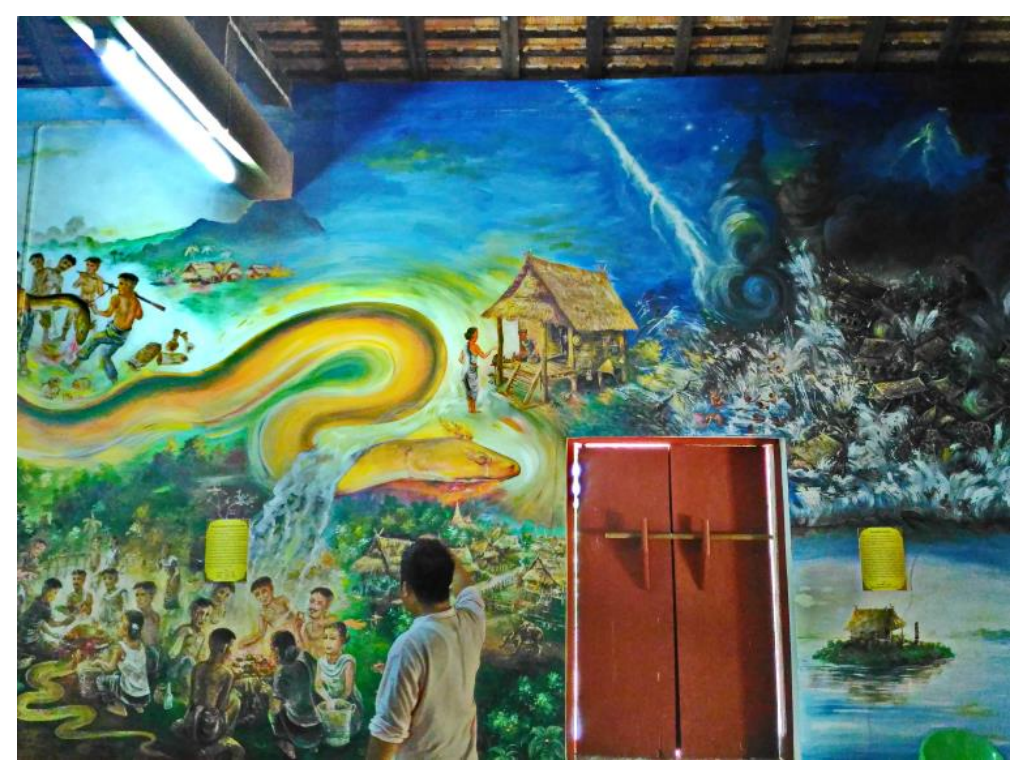

The legend of the Yonok kingdom has given rise to a variety of tangible heritage, including the murals in the ceremonial hall of Wat Phrathat Doi Kaew temple in Chiang Mai's Mae Chan district, Thailand. (Photo: Nakai, 2017). 
In modern societies vernacular knowledge is celebrated as valuable heritage, but is often wrongly associated with illiterate societies, and dismissed as outdated and irrational (Dundes, 2007, p. 56) [see Figure 5]. According to the secular and individualistic values of modern society, people are encouraged to make decisions based on expert knowledge of specialists, rather than relying on traditional institutions of family, religion, or community - or on the accumulated wisdom and customs of the local community (Giddens, 1991, p.198). In the field of natural disaster management, a top-down transfer of information and technologies to recipients is promoted while vernacular knowledge is dismissed (Mawere, 2015, pp. 19-20). This hinders the smooth integration of vernacular knowledge into modern natural disaster management.

Figure 5. Statues of Jizō deities facing the epicentre of the 2011 earthquake.

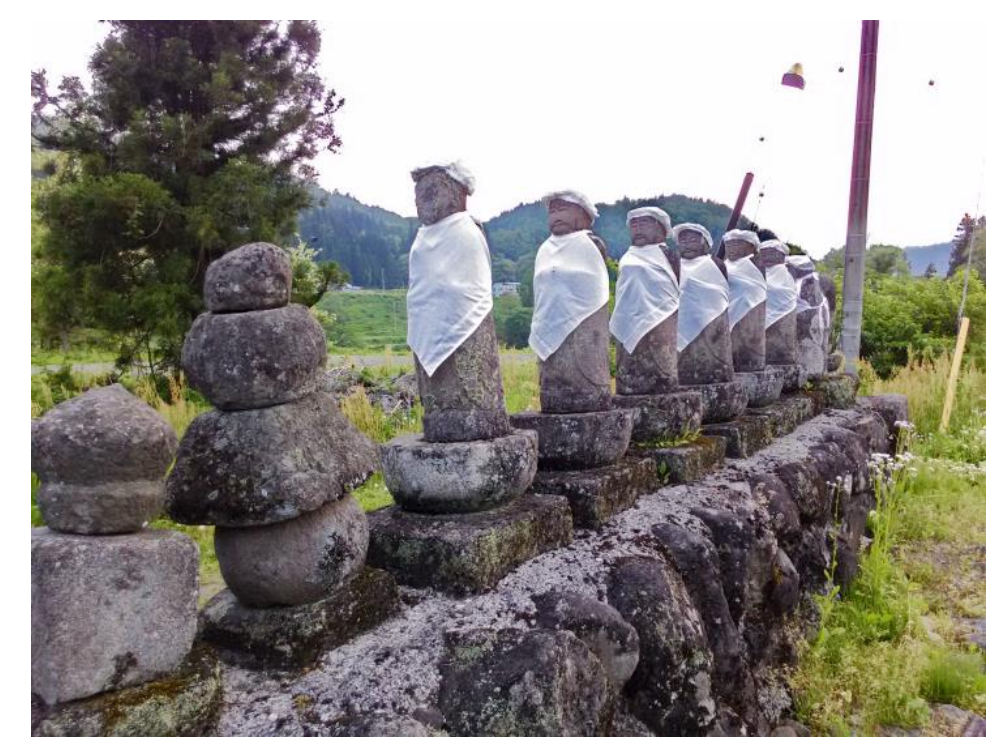

Thirteen hours after the Great East Japan Earthquake, a 6.7 magnitude earthquake struck northern Nagano Prefecture. Despite heavy damage to infrastructure, no direct fatalities were reported (Saito, 2012). The people of Nishi-Otaki village, only $10 \mathrm{~km}$ from the epicentre, found that Jizo statues in their village were facing the direction of the epicentre. They rumoured that the Jizō were protecting them. This rumour can be easily dismissed as unscientific, but it is an attempt to preserve and pass on to future generations the memory of the forgotten earthquake. (Photo: Nakai, 2016).

However, Monsoon Asian societies have begun to realise the importance of local resilience to natural hazards. In 2005, the Hyogo Framework for Action (2005-2015) was adopted at the second United Nations World Conference on Disaster Reduction, marking a critical shift in the earlier disaster management that focused on post-disaster relief and recovery. This action plan stipulates the use of knowledge management and education to improve resilience of local communities to natural hazards. Specifically, Article 3 refers to the promotion of local participation as an integral part of sustainable disaster management (International Strategy for Disaster Reduction, 2009, p. 9). To 
eTropic 20.2 (2021) Special Issue: Tropical Imaginaries and Climate Crisis

achieve this goal, a number of innovative initiatives have been undertaken in Monsoon Asia (e.g., Fire and Disaster Management Agency of Japan, 2008; Department of Disaster Prevention and Mitigation of Thailand, 2015, pp. 16-20).

\section{Unforeseen Disasters in the Age of Climate Change}

There is growing concern among meteorologists that climate change will make extreme weather events and associated disasters more frequent and intense in the future. In Monsoon Asia, recent years have seen what government agencies, scientists and other experts call "unforeseen" phenomena continue to occur despite many decades of natural disaster prevention and mitigation efforts. This alarming trend cannot be attributed to climate change alone; it also stems from the longstanding structural problems of modern disaster management.

Policymakers and government agencies prioritise disaster management according to urgency and feasibility. Natural disasters with long return periods are not considered urgent issues, even if their impact is high. The limitations of modern disaster management are observable in sediment management in the Kiso Valley, located in the upper reaches of the Kiso River which winds through the mountainous region of central Japan. Covered on both sides by steep mountain ranges, this V-shaped valley has suffered numerous sediment disasters, and technical measures such as the construction of sediment dams, riverbank reinforcement, and reforestation, have been implemented for over 100 years (Sasamoto, 1994). While national sediment management policies in Japan are designed to cope with the amount of sediment generated by a 5-to-10-year rainfall at the national level, sediment management in the Kiso Valley is designed to withstand sediment from a 30-year rainfall (Tajimi Erosion Control and National Highway Office, Chūbu Regional Development Bureau, Ministry of Land, Infrastructure and Transport, 2012, p.5). Nevertheless, despite such longstanding efforts, there is always the possibility of events that exceed the scope of modern disaster management plans, as was the case with the fatal debris flow in the valley town of Nagiso, triggered by a torrential rainfall of approximately $90 \mathrm{~mm}$ in one hour on July 9, 2014 (Japan Erosion Control Association, 2014).

In the future, the differences in precipitation between wet and dry areas and between wet and dry seasons are expected to become greater in many parts of the world. In Japan, annual precipitation has been fluctuating since the 1970s, and by the end of the 21 st century, the occurrence of short duration heavy rainfall is expected to increase by $10 \%$ to $25 \%$ in all regions and seasons, while the number of days without precipitation is also expected to increase (Ministry of the Environment Ministry of Education of Japan et al., 2018, pp. 37-38). The frequent occurrence of extreme 
weather associated with climate change calls for a revision of existing disaster management.

As in other parts of Monsoon Asia, Thailand's disaster management system lacks systematic collection and management of meteorological data, especially at the regional level (United Nations Development Programme, 2016, p. 63). The great flood of 2011 in the Chao Phraya and Mekong river basins claimed more than 680 lives and caused 1.43 trillion baht (US\$46.5 billion) in damages (World Bank, 2012, p. 2). The Thai prime minister called the disaster an "unpredictable" catastrophe ("Pu' survives!," 2017) [see Figures 6 \& 7]. According to the Thailand Meteorological Department (n.d.), the country's first meteorological observatory was established in Bangkok in 1923, initially to collect precipitation and temperature information for the Irrigation Department and the Navy. The government gradually expanded the coverage to provincial areas (e.g., Songkhla in 1936, Chiang Mai in 1942, Lopburi, Chachoengsao, and Ubon Rachathai in 1951, Phuket in 1985, and Khonkaen in 1992). Although Thailand became a member of the World Meteorological Organization, and began to collect data in a more systematic manner in 1949, long-term meteorological data is still limited both in terms of duration and areas covered, making accurate data analysis and forecasting difficult.

Figure 6 \& 7. The 2011 Flood in Bangkok, Thailand.
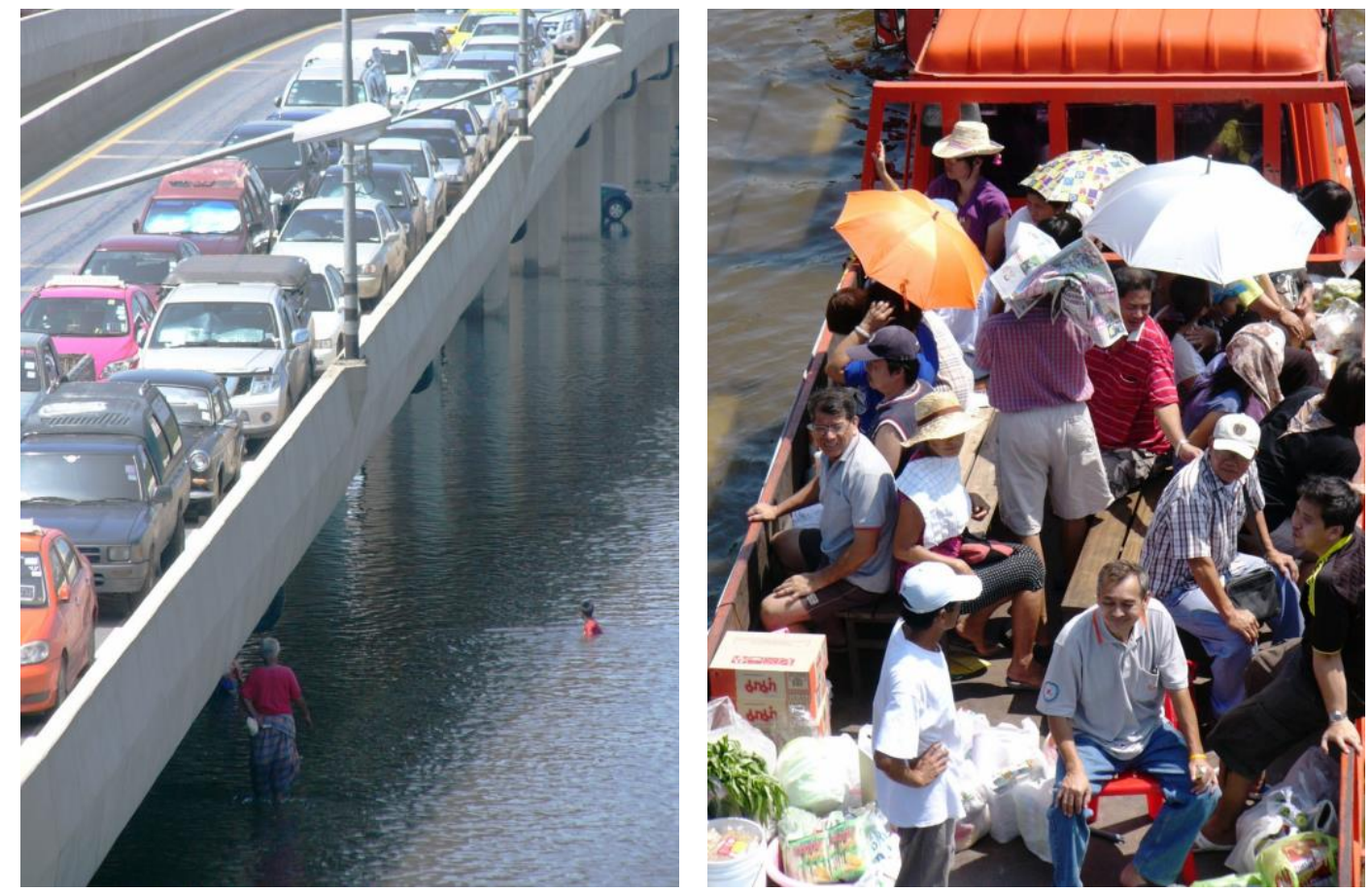

The October 2011 Flood near the Thailand government complex buildings in Bangkok (left) and an emergency vehicle carrying goods and people (right) (Photo: Nakai, 2011) 
eTropic 20.2 (2021) Special Issue: Tropical Imaginaries and Climate Crisis

When a devastating tsunami hit the Andaman Sea coast of Thailand on December 26, 2004, one geologist described it as an "unexpected disaster" (Jankaew, 2014). It has long been known that powerful earthquakes occur regularly at the plate boundary off the west coast of Sumatra. It is also known that there are oral traditions of giant waves along the coasts of the Indian Ocean and the Andaman Sea, but it was only after the 2004 tsunami that Thai scientists and administrators finally took the risk of tsunamis seriously. A post-tsunami geological survey revealed that powerful tsunamis struck the Andaman Sea coast in south-western Thailand at intervals of about 550 years (Prendergast et al., 2004).

Even a country like Japan, which has devoted more resources to collecting data on, and preparing for natural disasters than many other countries, still has limited natural disaster management capacity. Shortly after a massive earthquake struck the northeastern region on March 11, 2011, massive tsunamis hit the Tokyo Electric Power Company (TEPCO)'s Fukushima nuclear power plant, causing a meltdown as the plant lost power. The TEPCO's accident report (2011, p.10) claimed that although adequate precautions had been taken, the tsunamis were much stronger than they had initially expected. Prior to the accident, a group of researchers had raised concerns about the inadequacy of existing safety measures against powerful tsunamis based on their simulation of a tsunami associated with the 869 historical earthquake (Satake et al., 2008; Shimazaki, 2011, p.1004). However, the TEPCO, and its technical advisor, the Japan Society of Civil Engineers, dismissed this warning, citing insufficient data on past earthquakes in the vicinity of the power plant (cited in Shimazaki, 2011, p.1004). Thus, due to the structural limitations of modern disaster management, unpredictable events are created.

\section{Self-responsibility in Modern Disaster Management}

In addition to infrastructural and technical support, disaster management also uses information campaigns to lead the public to recognise the risk of natural disasters, and to voluntarily take actions to protect themselves. Such intervention, known as the cognitive adjustment approach allocates self-protection as the responsibility of the individual, and to blame those who fail to comply (Gaillard \& Texier, 2010, p. 82). However, it must be noted that vulnerability to natural disasters is not necessarily due to negligence or lack of rationality, but can be due to structural problems in society (Gaillard \& Texier, 2008). For example, it is known that socially and economically deprived migrants have no choice but to live in places with a higher risk of natural hazards [see Figure 8]. 
Figure 8. A submerged slum in Latphrao district, Bangkok.

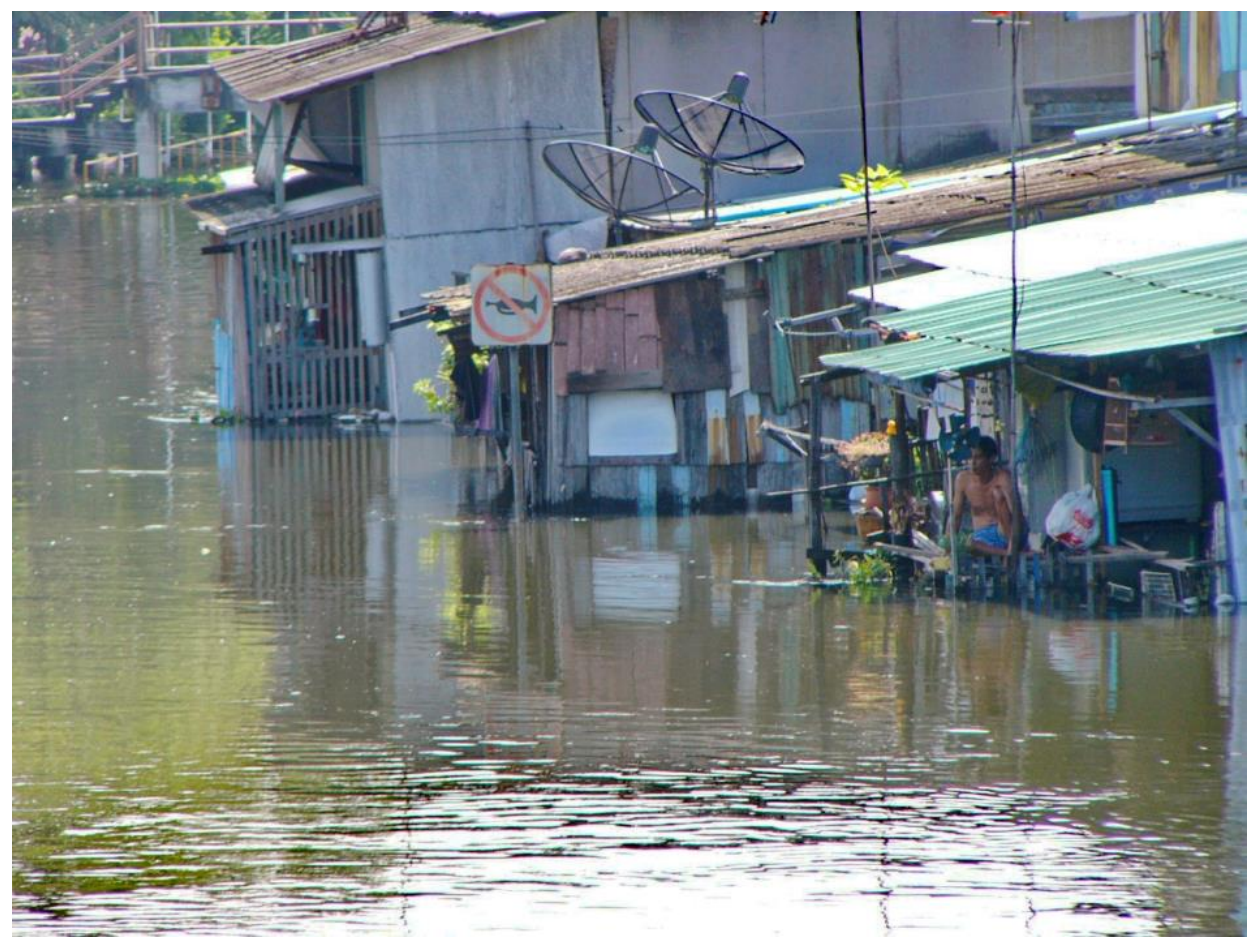

Given the rapid growth of the world's population and increasing rural-urban migration, especially in less developed countries, competition for life chances - from jobs to housing - has intensified. The urban poor, albeit aware of their vulnerability to natural hazards, are too deprived to take appropriate action. (Photo: Nakai, 2011)

Shōji Sasamoto (1994, p.130) points out that most disaster-related research is led by scientists, whose primary goal is to elucidate the mechanisms of natural disasters, ignoring the social and cultural aspects. As social beings, humans cannot always avoid the risks of natural hazards even if they are aware of them. After the Meiji Sanriku Tsunami (1896) struck the Pacific coast of north-eastern Japan, many of the victims refused to accept the government's relocation plan. Fumio Yamashita (2008, p. 148), a local historian who himself was from a family of fishermen in the north-eastern region, explained that most of the victims of the 1933 tsunami were fishermen and their families chose to live near the ocean again because of the accessibility to the sea and competition among fishermen [see Figure 9].

The reaction of the Japanese fishermen mirrors that of settlers in the seaside town of Aitape, Papua New Guinea, which was hit by a tsunami in 1998. A post-tsunami survey found that as memories of the disaster quickly faded, the settlers tended to return to the affected area because of the advantages of living along the coast (Davies, 2002, p. 41). Given the complexity of vulnerability to natural hazards, those involved in disaster management need to take this social dimension into greater consideration. 
Figure 9. Hibarino Beach, Ishinomaki City, 13 days after the 2011 tsunami.

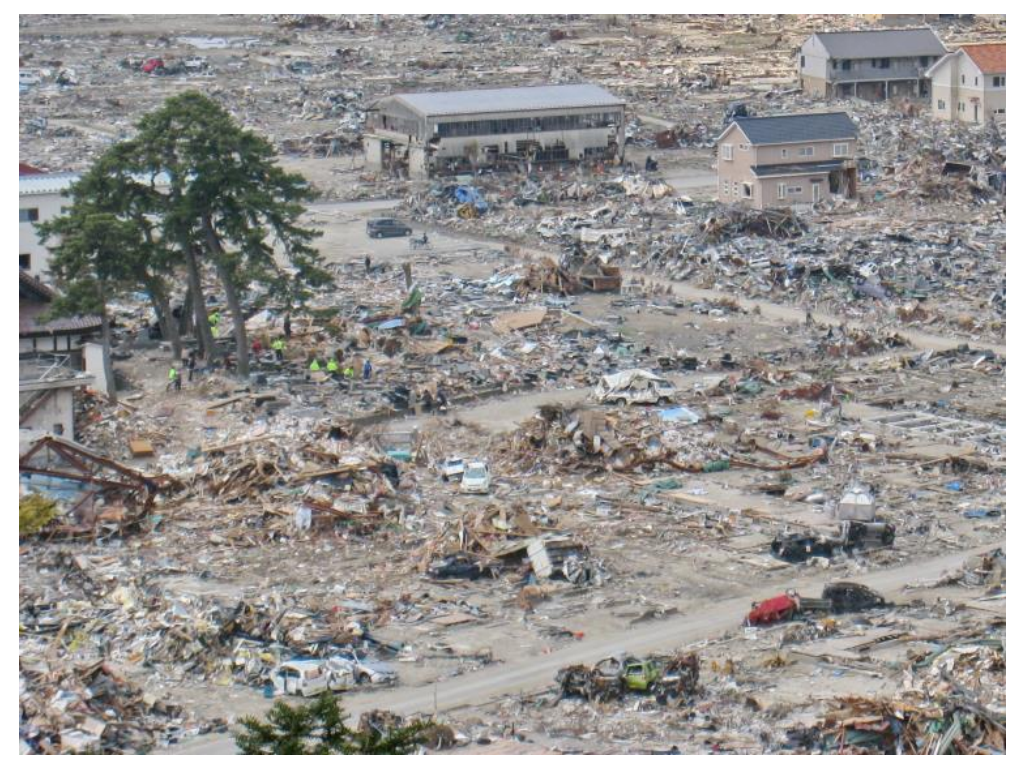

Ishinomaki, a port town in Miyagi Prefecture, had been repeatedly hit by tsunamis, but many of the survivors had returned to the bay area. The 2011 tsunami again caused extensive damage, with 3,553 people killed, 418 missing, and 56,708 buildings damaged (Fire and Disaster Management Agency of Japan, 2021, March 9, p. 1). (Photo: Konno, 2011).

\section{Complacency about Modern Disaster Management}

A number of studies have pointed out that advances in the technological management of natural hazards have led people to underestimate the risks of natural disasters. In this regard, Nobuo Shutō, a Japanese civil engineer (2006, p.188), pointed out the anti-tsunami infrastructure introduced along the north-eastern coastline of Japan after the 1960 Chilean tsunami ironically hindered the subsequent progress of anti-tsunami measures:

The reality in Japan today is that houses line up to the very edge of seawalls, most residents do not evacuate after a strong earthquake, and most of the participants in disaster drills are Chilean tsunami survivors. Even in Taro [a tsunami-prone district in Iwate prefecture], where people are keen on tsunami prevention, the number of participants in evacuation drills is decreasing. We are apparently safer now than we were before the Chilean tsunami, but may be more vulnerable to tsunamis much larger than the Chilean tsunami.... in retrospect, it is undeniable that the "false sense of security" provided by infrastructures has hindered the development of land use planning and disaster prevention systems. [my translation] 
eTropic 20.2 (2021) Special Issue: Tropical Imaginaries and Climate Crisis

Shutō's fears were realised when a tsunami struck on 28 February, 2010. After a powerful earthquake occurred off the coast of south-central Chile, the Japan Meteorological Agency issued a tsunami warning for the entire Pacific coast. However, according to a post-tsunami survey, in Kamaishi City, Iwate Prefecture, less than half of the residents (45.5\%) evacuated to a safe place after receiving an evacuation advisory. The remaining 54.5\% thought that they were safe, and did not follow the advisory (Kanai \& Katada, 2011). Then, only one year later, another tsunami returned to the city - far more powerful this time, it claimed the lives of over 1,200 people.

Such a state of complacency is not limited to Japanese society, but is a general trend in other parts of Monsoon Asia. In this region, the effects of climate change have become more pronounced in recent years, and "unforeseen" events have become more frequent and more intense.

It is true that disaster management strategies are updated and made more robust in the wake of unprecedented events. For example, the 2011 flood in Thailand led to the improvement or introduction of technical and infrastructural measures against flooding, such as retention basins, rainwater drainage pumps, river embankments, and early warning systems, mainly within Greater Bangkok (Otomo, 2013, p. 245). However, people living in Monsoon Asia have become dangerously complacent about their own safety: they abandoned the local wisdom that has long protected them from natural hazards, and have instead come to rely on science and technology introduced by outside experts. As a result, they can no longer imagine the growing risk of natural disasters in the age of climate change.

\section{Vernacular Knowledge in the Age of Climate Change}

Given the limitations of science and technology driven disaster management, government agencies and experts in disaster management have come to realise that the top-down transfer of "hard" technologies cannot effectively prevent or mitigate natural disasters. As a result, there have been efforts to integrate "soft" technologies into modern disaster management to increase the resilience of society to natural hazards.

In Japan, for example, shortly after the Great Hanshin-Awaji Earthquake in 1995, the Disaster Countermeasures Basic Act of 1961 was amended to promote the participation of local communities and volunteerism as part of the national strategy (Ministry of Internal Affairs and Communications of Japan, 2008). Considering the lessons learnt after the 2011 Great East Japan Earthquake, the Act was amended once again in 2013 to stipulate that citizens, along with the national and local governments, have a duty to pass on the lessons of past disasters to future 
eTropic 20.2 (2021) Special Issue: Tropical Imaginaries and Climate Crisis

generations. This amendment to the Act, for example, has led to a nationwide recommendation to learn about natural disasters in compulsory education in order to develop disaster resilience among youngsters (Takeda et al., 2017).

Turning to Thailand, which has also been experiencing severe disasters in recent years, natural disasters were, until a decade ago, just one of many security crises for the government, along with war and terrorism. At that time, its disaster management strategy focused on post-disaster assistance, which was overseen by the Civil Defence Department and the National Security Council. However, in the wake of the 2004 Indian Ocean Tsunami, the government enacted the Disaster Prevention and Mitigation Act in 2007, and established the Department of Disaster Prevention and Mitigation (DDPM) to oversee national disaster management planning and interagency coordination. Thailand, as a signatory to the Hyogo Framework for Action, has designated the DDPM to oversee the implementation of the framework, including integrating traditional and indigenous knowledge, and cultural heritage, into national disaster management plans (International Strategy for Disaster Reduction, 2009, p. 9). Although still in its early stages, concerted efforts have also begun to be organised to utilise vernacular knowledge for disaster management in Thailand.

\section{Passing on Vernacular Knowledge to Future Generations}

In Monsoon Asia, there is growing recognition of the potential for using previously overlooked vernacular knowledge in disaster management, but the preservation of vernacular knowledge and its integration into modern disaster management is not an easy task. Due to the changing social conditions in Monsoon Asia, people are more mobile and less connected within their local communities, making it difficult for local memories and know-how to be passed on to future generations [see Figure 10]. A study of tsunami-prone coastal communities in Papua New Guinea, for example, found that local memories of the tsunami were limited to one generation (Davies, 2002, p. 38). Vernacular knowledge is in danger of disappearing through modernisation, and urgent action is needed to preserve it and pass it on to future generations.

In Japan, a number of initiatives have been implemented to preserve vernacular knowledge about natural disasters as part of its resilience-building programme. A prime example is the Upper Tenryū River Basin initiative, which has been coordinated by the Central Regional Development Bureau (CRDB) of the Ministry of Land, Infrastructure and Transport (MLIT) since the 1980s. The Tenryū River, which flows through three prefectures in central Japan, is known as the "raging river" because of its volatility, causing devastating floods and sediment disasters in June 1961 and September 1983. Subsequently, the CRDB's Upper Tenryū River Basin Office initiated a range of innovative projects using vernacular knowledge of local hazards. 
eTropic 20.2 (2021) Special Issue: Tropical Imaginaries and Climate Crisis

In order to overcome the challenges in passing on vernacular knowledge due to the loss and deterioration of historical materials on local disasters, and the ageing of the population, the public and private sectors collaborated to launch various projects (Research Unit for Studying How to Pass on Lessons Learned from Natural Disasters in Tenryū River Upper Reaches, 2009, p. 1). The CRDB has been working with local stakeholders, such as schools, researchers, artists, museums, and administrative agencies to engage local communities in preserving vernacular knowledge of the river and natural disasters - disaster-related proverbs, folktales, place names, monuments, natural objects, and indigenous technology for flood control - as part of school education and community resilience-building activities [see Figure 11 \& 12].

\section{Figure 10. A Moken 'Sea Gypsy' fisherman with a tsunami shelter in background.}

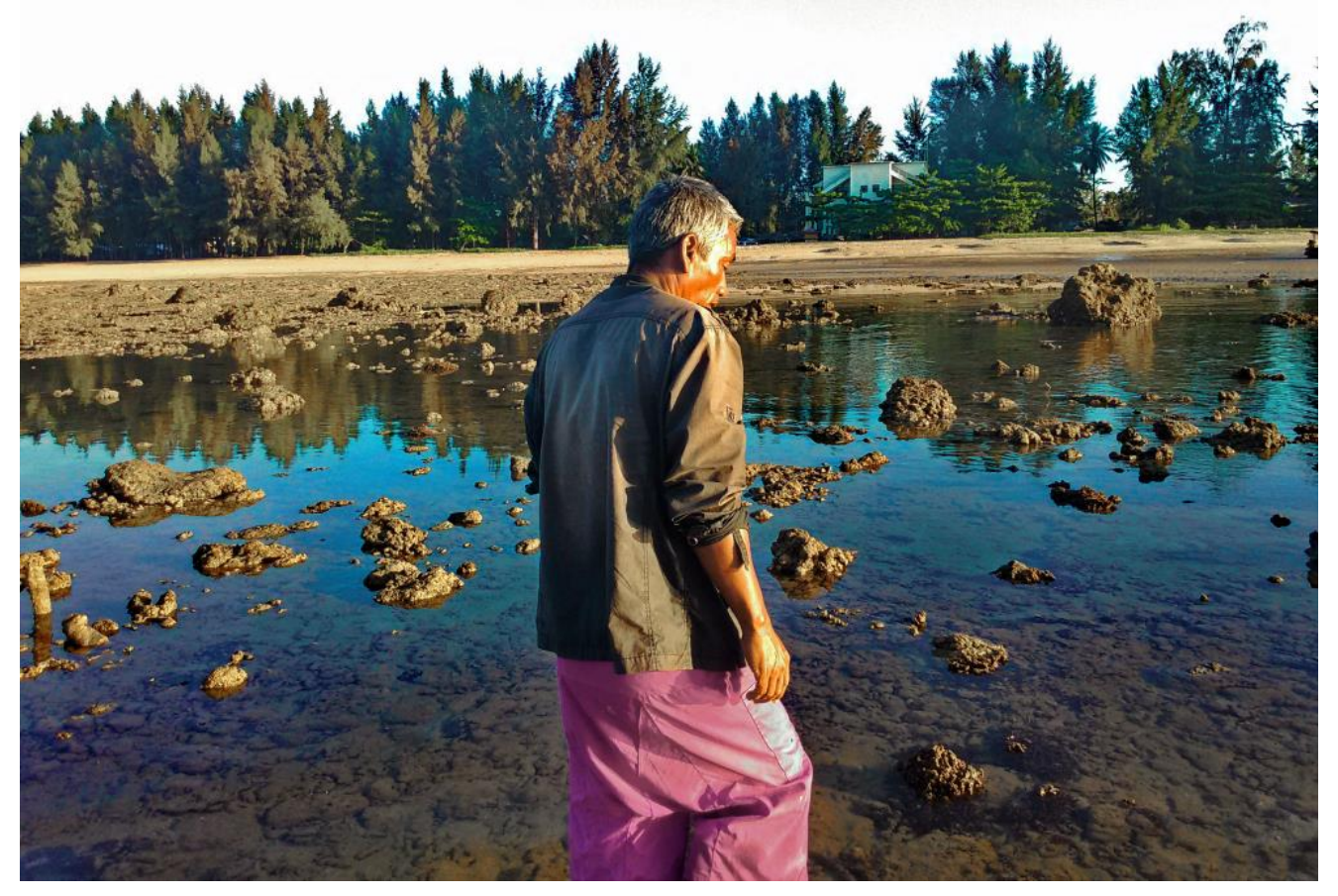

Hong, a Moken from Phang Nga Province, Thailand, is a survivor of the 2004 Indian Ocean Tsunami. The devastation in Phang Nga province was so severe that the death toll in that province accounted for $78 \%$ (4,225 people) of the total casualties in Thailand (Department of Disaster Prevention and Mitigation cited in United Nations Country Team in Thailand, 2005, p.14). The Moken people of the Surin Islands in the northern part of the province are reported to have survived the tsunami by following the advice of the oral tradition of the "seven-storey man-eating wave" (Narumon, 2014). However, the existence of tsunami-related folklore was not known to his community in Takuapa district (Hong, K, personal communication, January 14, 2016). (Photo: Nakai, 2016). 
eTropic 20.2 (2021) Special Issue: Tropical Imaginaries and Climate Crisis

Figure 11 \& 12. Passing on vernacular knowledge.
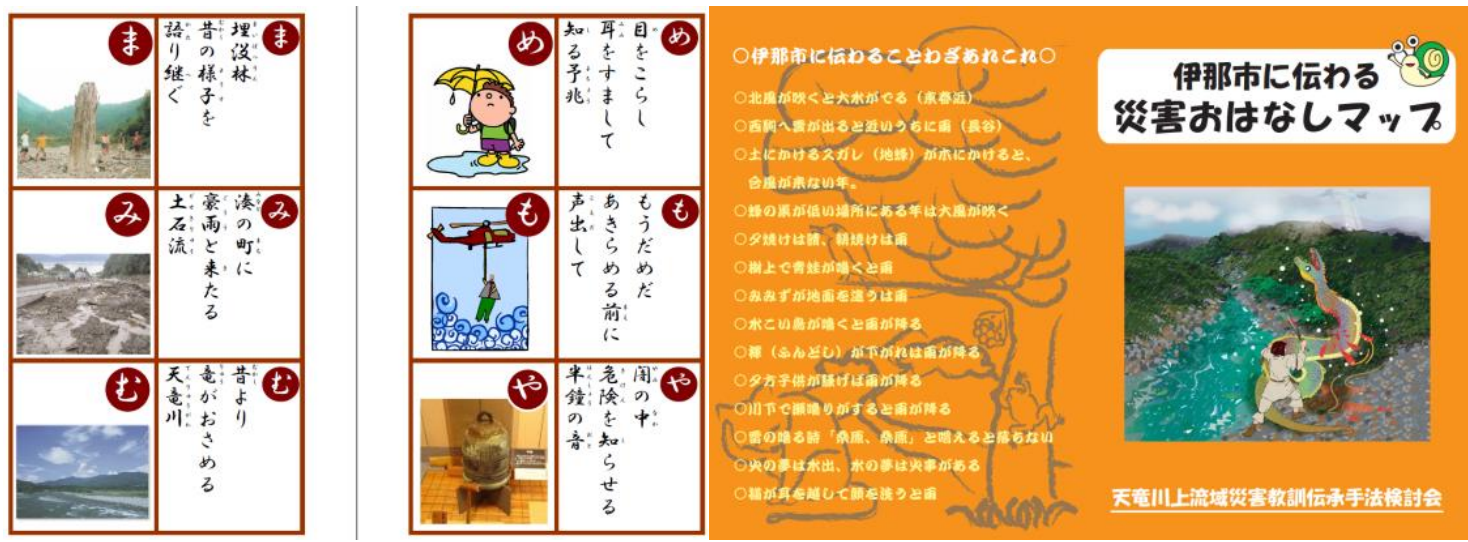

Tenryū Karuta (Tenryū karuta playing cards, left), and Tales of disasters from Ina City (right) (Research Unit for Studying How to Pass on Lessons Learned from Natural Disasters in Tenryū River Upper Reaches, 2009).

The Tenryū initiative has developed the following five core activities to pass on local disaster culture within the community: 1 . School lessons to children on local disasters and disaster management skills. 2. Field trips to disaster areas in conjunction with activities of a local community centre. 3. Field trips to disaster-related heritage sites, such as old civil engineering structures along the river, memorials to local disasters, and sites associated with disaster-related legends. 4. Periodic lectures on natural disasters in conjunction with local government disaster management events. 5 . 'Disaster Prevention Cafes' set up in museums and other public places, where even people who are not usually interested in natural disasters can casually drop by and learn about disaster prevention and mitigation. Other educational materials are also provided in a variety of formats, including the booklet series Kataritsugu Tenryu (Passing on stories of the Tenryū, 1986-), picture books, websites, karuta playing cards, public lectures, performances, and other public events.

In tsunami-prone north-eastern Japan, the proverb tendenko ("flee from tsunami alone") has been handed down as a stern reminder of the importance of swift evacuation in case of a tsunami (Yamashita, 2008). Prior to the 2011 tsunami, the proverb, along with the local history of tsunamis, was reiterated during evacuation drills and hazard mapping in schools to stress the importance of timely and voluntary evacuation. Although the 2011 tsunami claimed more than 1,200 lives in the city, only five of the 2,926 students lost their lives thanks to their swift and voluntary evacuation (Katada, 2012, p. 38).

Similarly, the islanders of Simeulue, Aceh, Indonesia, are known to have evacuated during the 2004 Indian Ocean Tsunami following the oral tradition known as smong. Smong is a group of songs and poems recording in the local language about the 1907 
eTropic 20.2 (2021) Special Issue: Tropical Imaginaries and Climate Crisis

tsunami, which killed $50 \%$ to $70 \%$ of the islanders. After the earthquake tremor in 2004 , the islanders noticed that the tide was receding rapidly. As smong taught them, they voluntarily evacuated to higher ground. Despite the island's proximity to the epicentre, only three of over 88,000 islanders were killed (Rahman et al., 2017; Syafwina, 2014, p. 7). This episode prompted researchers and aid organizations to preserve smong in both traditional and new media, such as Nandong, the traditional recitation of a story as a song or poem, and booklets, with the aim of building community resilience to tsunamis. Furthermore, after a series of natural disasters in 2018, the Indonesian government has officially acknowledged the importance of vernacular knowledge in its disaster management efforts (International Federation of Red Cross \& Red Crescent Societies, 2021).

\section{Conclusion - Imaginative Futures}

While tremendous progress has been made in the scientific management of natural hazards, it is also true that people in Monsoon Asia have become disengaged from disaster management efforts. Many local communities in the region have become dependent on outside experts or government agencies for protecting their lives and property from natural hazards. This situation hinders the people from taking initiative in natural disaster management, and in realising the growing risk of extreme weather events due to climate change.

Even more alarming is the rejection of the cultural resources that have been cultivated in local communities to protect the people from natural hazards. Unhealthy dependence on outside experts, who do not necessarily understand the particularities of local communities, erodes local resilience to natural hazards, and may in turn lead to the recurrence of unexpected disasters such as those illustrated in this article. As the lessons from recent large-scale disasters indicate, top-down knowledge and technological transfer alone is not sufficient to strengthen local resilience to natural hazards, and even with modern science and technology, it is still difficult to accurately assess the risks of natural hazards, and prepare prevention and mitigation measures against them.

Imaginative integration of vernacular knowledge and modern disaster management, as in the examples from Japan, Thailand, and Indonesia, holds promise for detecting the signs of climate change natural hazards, and coping with the growing risks of natural disasters. In these countries, innovative activities have been undertaken to preserve vernacular knowledge and incorporate it into education and community activities. Thus encouraging active community participation in building disaster resilience. 
eTropic 20.2 (2021) Special Issue: Tropical Imaginaries and Climate Crisis

Nevertheless, research on the interface between vernacular knowledge and modern disaster management is still limited in volume and scope. More research is needed to facilitate the integration of vernacular knowledge into modern disaster management as Monsoon Asia faces an increasingly uncertain future. 
eTropic 20.2 (2021) Special Issue: Tropical Imaginaries and Climate Crisis

\section{References}

Amrith, S. S. (2018). Unruly waters: How mountain rivers and monsoons have shaped south Asia's history. Basic Books.

Arunotai, N. (2014). Prasopkankhongchaomoken naikanpachaengkaptsunami penyangraibang? [What did the Moken experience during the tsunami?]. In N. Arunotai (Ed.), Thaksawatanatam chaole roirueangraochaole [Cultural skills of the sea dwellers: Many stories of the sea dwellers], (pp. 111-113). Parbpim.

Asian Development Bank. (2015). Southeast Asia and the economics of global climate stabilization. https://www.adb.org/sites/default/files/publication/178615/seaeconomics-global-climate-stabilization.pdf

Association of Southeast Asian Nations, Government of Myanmar, \& United Nations Country Team in Myanmar. (2008). Post-Nargis joint assessment. https://www.recoveryplatform.org/assets/publication/PostNargis Joint Assessment.pdf

Azzali, S., Law, L., \& Lundberg, A. (2020). Sustainable Tropical Urbanism: Insights from Cities of the Monsoonal Asia-Pacific. eTropic: electronic journal of studies in the Tropics, 19(2), 1-24. https://doi.org/10.25120/etropic.19.2.2020.3777

Basic act on disaster management 1961. (1961). S. 7.2, 8.2.13 (Japan) http://www.bousai.go.jp/taisaku/kihonhou/pdf/h24 01 aratamebun.pdf

Clift, P. D., Tada, R., \& Zheng, H. (2010). Monsoon evolution and tectonics-climate linkage in East Asia: Climate linkage in Asia. Geological Society of London. https://doi.org/10.1144/SP342.1

Davies, H. (2002). Tsunamis and the coastal communities of Papua New Guinea. In R. Torrence, \& J. Grattan (Eds.), Natural disasters and cultural change, (pp. 28-42). Routledge.

Department of Disaster Prevention and Mitigation of Thailand. (2015, April). National progress report on the implementation of the Hyogo framework for action (20132015). https://www.preventionweb.net/files/41674 THA NationalHFAprogress 201315.pdf

Dundes, A. (2007). Folklore as a mirror of culture. In S. J. Bronne (Ed.), The meaning of folklore (pp. 53-66). Utah State University Press.

Fire and Disaster Management Agency of Japan. (2008). Zenkoku saigai denshō jōhō [National disaster lore information]. https://www.fdma.go.jp/publication/database/database009.html

Fire and Disaster Management Agency of Japan. (2021, March 9). Heisei 23-nen (2011-nen) Tōhokuchihō Taiheiyōjishin (Higashi-nihon daishinsai). [The 2011 off the Pacific coast of Tohoku Earthquake (Great East Japan Earthquake) (161st report)]. https://www.fdma.go.jp/disaster/higashinihon/item/higashinihon001 12 03-01 02.pdf

Gaillard, J.-C., \& Texier, P. (2008). Guest editorial. Disaster prevention and management, 17(3), 346-349. https://doi.org/10.1108/dpm.2008.07317caa.001

Gaillard, J.-C., \& Texier, P. (2010). Religions, natural hazards, and disasters: An introduction. Religion, 40(2), 81-84. https://doi.org/10.1016/j.religion.2009.12.001

Haruyama, S. (2000). Environmental change and natural hazard of the farm-land on the Red River Delta, Vietnam. Journal of the Japanese Society of Irrigation, Drainage and Reclamation Engineering, 68, 15-20.

IPCC, (2021, In Press). Summary for Policymakers. In Climate Change 2021: The Physical Science Basis. Contribution of Working Group I to the Sixth Assessment Report of the Intergovernmental Panel on Climate Change [Masson-Delmotte, V., P. Zhai, A. Pirani, S. L. Connors, C. Péan, S. Berger, N. Caud, Y. Chen, L. Goldfarb, M. I. 
eTropic 20.2 (2021) Special Issue: Tropical Imaginaries and Climate Crisis

Gomis, M. Huang, K. Leitzell, E. Lonnoy, J.B.R. Matthews, T. K. Maycock, T. Waterfield, O. Yelekçi, R. Yu and B. Zhou (eds.)]. Cambridge University Press. International Federation of Red Cross and Red Crescent Societies. (2021, March 17). Emergency plan of action final report Indonesia: Earthquakes and tsunamis Sunda Straits Tsunami. https://reliefweb.int/report/indonesia/indonesia-earthquakesand-tsunamis-sunda-straits-tsunami-emergency-plan-action-0

International Strategy for Disaster Reduction. (2009). Hyogo framework for action 2005-2015: Building the resilience of nations and communities to disasters: extract from the final report of the World Conference on Disaster Reduction (A/CONF206/6). https://www.unisdr.org/2005/wcdr/intergover/official-doc/L-docs/Hyogo-frameworkfor-action-english.pdf

Itō, Y. (2010). Kōzui to ningen: Sono sōkoku no rekishi [Flood and man: history of the conflicts]. Kokonshoin.

Jankaew, K. (2014, December 25). Boxing Day Tsunami 10 years later. Chulalongkorn University Geology.

http://www.geo.sc.chula.ac.th/10years tsunami/?fbclid=IwAR3vLfy89Mz1ozY2IG6Yw dfRWSHS9csBWyGiLqO0EJVBuv7W 5csdhmPiLw

Japan Sabo Association. (2014, July 16). Heisei 26-nen 7-gatsu kokonoka Naganoken Kisogun Nagisomachi Yomikaki de hasseishita dosekiryūsaigai nituite [Debris flow in Yomikaki, Nagiso Town, Kiso County, Nagano Prefecture, July 9, 2014]. http://www.sabo.or.jp/saigai/20140709.htm

Kanai, M. \& Katada, T. (2011). Tsunamishuraiji no juminhinan o yūhatsusuru shakaitaio no kentō: 2010nen Chirijishin tsunami no hinan jittai kara ["Social correspondences to urge residents to evacuate at tsunami arrival-According to the actual situation of residents' response at Chile earthquake tsunami in 2010"]. Bōsaijōhō [Journal of Disaster Information Studies], 9, 103-113.

Katada, T. (2012). Kodomotachi o mamotta 'shisei no bōsai kyōiku': Ōtsunami kara ikinuita Kamaishishi no jidō/seito no kōdō ni manabu ['Disaster prevention education on attitude' that protected children: Learning from the actions of children and students in Kamaishi City who survived the great tsunami]. Journal of Disaster Information Studies, 10, 37-42.

Kawakatsu, H. (1997). Bunmei no kaiyō shikan [A maritime history of civilisation]. Chuōkōronshinsha.

Kyuma, K. (2009, October 5). Nature and agriculture in Monsoon Asia. [Keynote address] Monsoon Asia Agro-Environmental Research Consortium Symposium 2009, Tsukuba, Japan. http://www.naro.affrc.go.jp/archive/niaes/marco/marco2009/english/program/S0 Keynote Kyuma Kazutake.pdf

Lundberg, A. (2021). Balinese dancer wearing a gas mask: climate change and the tropical imaginary. Scottish Geographical Journal, 136, 91-100. https://doi.org/10.1080/14702541.2020.1858589

Lundberg, A. (2003). Voyage of the Ancestors. Cultural Geographies, 10, 64-83. https://doi.org/10.1191/1474474003eu262oa

Luong, H. V. (2017). The reconstruction of heritage in rural Vietnam: An analysis of state and local dynamics. In H.-H., Hsiao, Y.-F., Hui, \& P. Peycam. (Eds.), Citizens, civil society, and heritage-making in Asia (pp. 86-113). ISEAS-Yusof Ishak Institute.

Mawere, M. (2015). Indigenous knowledge for disaster risk management in Africa: Some showcases from Zimbabwe. In M. Mawere \& S. Awuah-Nyamekye (Eds.), Between rhetoric and reality: The state and use of indigenous knowledge in Post-Colonial Africa (pp. 19-38). African Books Collective. 
eTropic 20.2 (2021) Special Issue: Tropical Imaginaries and Climate Crisis

Ministry of the Environment, Ministry of Education, Culture, Sports, Science and Technology, Ministry of Agriculture, Forestry and Fisheries, Ministry of Land, Infrastructure, Transport and Tourism, \& Japan Meteorological Agency. (2018). Kikōhendō no kansoku·yosoku oyobi eikyōhyōka tōgōrepōto 2018: Nihon no kikōhendō to sonoeikyō [Climate change observation, projection, and impact assessment integrated report 2018: Climate change and its impacts in Japan]. http://www.env.go.jp/earth/tekiou/report2018 full.pdf

Mishra, O. P., Khare, N., Das, S. B., Kumar, V., Singh, J., Vandana, Singh, P., Ghatak, M., Shekhar, S., Tiwari, A., Gera, S. K., Mahto, R., \& Gusain, P. (2021). Glacial mass change-induced earthquakes in the Himalayan region of South Asia and its bearing to understand Arctic glaciers dynamics: proxy of climate change. In N. Khare (Ed.), Understanding present and past Arctic environments (pp. 433-455). Elsevier. https://doi.org/10.1016/B978-0-12-822869-2.00025-6.

Nakai, S. (2017, July 15). White eel and virtuous widow in lost city: Archiving Northern Thai folklore of natural disasters [paper presentation]. In Interface between local knowledge and scientific knowledge: Disaster management in Thailand. Globalized Thailand? Connectivity, conflicts, and conundrums of Thai studies. 13th International Conference on Thai Studies, Chiang Mai, Thailand. (pp. 1045-1075).

Okada, T. (1985). lizuka Kōji no ajiaron: Sonosenchū sengo [Kōjino lizuka's Asianism: Its interwar and post-war phases]. Jimbun Chiri [Japanese Journal of Human Geography], 37(5), 389-406.

Okae, T. (2019). Betonamu no nōgyō to nōchiseisaku [Agriculture and agricultural land systems in Vietnam]. Policy Research Institute of Japan's Ministry of Agriculture, Forestry and fisheries' country report. https://www.maff.go.jp/primaff/kanko/project/attach/pdf/200331 R01cr02 03.pdf Ongsakul, S. (2005). History of Lan Na. Silkworm Books.

Oppenheimer, M., B.C. Glavovic, J. Hinkel, R. van de Wal, A.K. Magnan, A. Abd-Elgawad, R. Cai, M. Cifuentes-Jara, R.M. DeConto, T. Ghosh, J. Hay, F. Isla, B. Marzeion, B. Meyssignac, \& Z. Sebesvari. (2019). Sea Level Rise and Implications for Low-Lying Islands, Coasts and Communities. In H.-O. Pörtner, D.C. Roberts, V. MassonDelmotte, P. Zhai, M. Tignor, E. Poloczanska, K. Mintenbeck, A. Alegría, M. Nicolai, A. Okem, J. Petzold, B. Rama, \& N.M. Weyer (Eds.), Intergovernmental Panel on Climate Change (IPCC) Special report on the ocean and cryosphere in a changing climate. https://www.ipcc.ch/srocc/chapter/chapter-4-sea-level-rise-and-implicationsfor-low-lying-islands-coasts-and-communities/

Otomo, N. (2013). Tai niokeru bōsaiseisaku to 'butsureki 2550-nen bōsai oyobi keigenhō' [Disaster prevention policies in Thailand and 'Disaster Prevention and Mitigation Act of B.E. 2550']. Gaikoku no rippō [Foreign Legislation], 251, 239-246.

Phraya Prachakitkorachak. (2014). Phongsawadan Yonok [Yonok chronicle]. Sipanya.

Prendergast, A. L., Cupper, M.L., Jankaew, K., \& Sawai, Y. (2012). Indian Ocean Tsunami recurrence from optical dating of tsunami sand sheets in Thailand. Marine Geology, 295-298, 20-27. https://doi.org/10.1016/j.margeo.2011.11.012

'Pu' rot! Popocho titok khadi ploy namthuamyai pi-54 chi pen phai thammachat ['Pu' survives! National anti-corruption commission dropped case on 2011 flood, citing natural disaster]. (2017, March 13). Thai Rath Online. https://www.thairath.co.th/news/politic/1068935

Rahman, A., Sakurai, A., and Munadi, K. (2017). The analysis of the development of the Smong story on the 1907 and 2004 Indian Ocean tsunamis in strengthening the Simeulue island community's resilience. International Journal of Disaster Risk Reduction, 29, 13-23. http://doi.org/10.1016/j.ijdrr.2017.07.015

Saito, Y. (2012). Naganokenhokubu-jishin niokeru Sakaemura no saigaitaiō 
eTropic 20.2 (2021) Special Issue: Tropical Imaginaries and Climate Crisis

nikansuru chōsa [Survey on Sakaemura's disaster response to the Northern Nagano Earthquake]. Shōbōkagaku to jōhō [Scientific Approaches for Fire and Information], $108,41-45$.

https://www.isad.or.jp/pdf/information provision/information provision/no108/41p.pdf

Sasamoto, S. (1994). Januke, ijin, kodama: rekishisaigai to denshō [The run-off of snake, others, tree spirits: The folklore of historical disasters]. Tokyo: Iwata-shoin.

Satake, K., Namegaya, Y., \& Yamaki, S. (2008). Numerical simulation of the AD 869 Jogan tsunami in Ishinomaki and Sendai plains. Annual report on active fault and paleoearthquake Researches, 8, 71-89.

Shimazaki, K. (2011). Yosokusaretanimokakawarazu higaisōteikara hazusareta kyodaitusnami [Great tsunamis that had been predicted but were not included in the damage estimates]. Kagaku [Science], 81(10), 1002-1006.

Shrestha, S. (2014). Assessment of water availability under climate change scenarios in Thailand. In S. Shrestha (Ed.), Climate change impacts and adaptation in water resources and water use sectors (pp. 9-23). Springer. https://doi.org/10.1007/978-3319-09746-6 2

Syafwina, S. (2014). Recognizing indigenous knowledge for disaster management: Smong, early warning system from Simeulue Island, Aceh. Procedia Environmental Sciences, 20, 573-582. http://doi:10.1016/j.proenv.2014.03.070

Tajimi Sediment Control and National Highway Office. (2012). Kisogawasuikei chokkatsu sabōjigyō Setsumeishiryō [Explanatory material of erosion and sediment control projects for the Kiso River system, implemented by the office]. http://www.cbr.mlit.go.jp/tajimi/senmon/iimusho naiyou/h23 gaiyo.pdf

Takeda, F., Takeuchi, K., \& Mizuyama, T. (2017). A Study on local governments' efforts to hand down lessons learned from disaster in Japan. GRIPS Discussion Papers 17-02, National Graduate Institute for Policy Studies.

'Tendeko' sanriku no chie, kodomotachi o sukuu ['Tendeko'-Wisdom of Sanriku saves children]. (2011, March 28). Yomiuri Online. https://www.yomiuri.co.jp/kyoiku/news/20110328-OYT8T00699.htm

Tenryūgawajōryūiki saigaikyōkunden shōshuhō kentōkai [Research Unit for Studying How to Pass on Lessons Learned from Natural Disasters in Tenryū River Upper Reaches] (2009). Tenryūgawajōryūiki saigaikyōkundenshō shuhō jissen no tebiki to jirei (an) [A guide and examples of disaster lesson transfer methods in the Upper Tenryū River Basin (Draft)] https://www.cbr.mlit.go.jp/teniyo/flood/densho/pdf/tebiki.pdf

Thai Meteorological Department. (n.d.). TMD history. https://www.tmd.go.th/en/aboutus/history.php

Tokyo Electric Power Company. (2011). Fukushima nuclear accident analysis report (Interim report of December 02, 2011). https://www.tepco.co.jp/en/press/corpcom/release/betu11 e/images/111202e14.pdf

Umesao, T. (1957). Bunmei no seitaishikan josetsu [Introduction to an ecological view of civilisation]. Chūōkōron 72(1), 32-49.

United Nations Country Team in Thailand. (2005, December 22). Tsunami Thailand, one year later - National response and the contribution of international partners. https://reliefweb.int/report/thailand/tsunami-thailand-one-year-later-nationalresponse-and-contribution-international

United Nations Development Programme. (2016). Thailand: Common country assessment. https://www.undp.org > docs > cca > TH-CCA-2016

Usman, M. (2016). A study on the enhancing earthquake frequency in northern Pakistan: is the climate change responsible? Natural Hazards, 82, 921-931. https://doi.org/10.1007/s11069-016-2226-z 
eTropic 20.2 (2021) Special Issue: Tropical Imaginaries and Climate Crisis

Watsuji, T. (1962). A climate: A philosophical study (B. Geoffrey, Trans.). Japanese Government's Printing Bureau. (Original work published 1935).

World Bank. (2012). Thai flood 2011. Overview rapid assessment for resilient recovery and reconstruction.

http://documents1.worldbank.org/curated/en/677841468335414861/pdf/698220WP0v 10P106011020120Box370022B.pdf

Yamashita, F. (2008). Tsunami tendenko: Kindainihon no tsunamishi [Tsunami tendenko: Modern history of tsunamis in Japan]. Shinnihon Shuppansha.

\section{Acknowledgements}

This article is part of the research project "Digital archive of disaster-lore in the Wiangnongom Wetlands, Chiang Rai, Thailand", supported by the Facility of Journalism and Mass Communication, Thammasat University. I thank Professor Attachak Satayanurak, Associate Professor Acharawan Isarangkura $\mathrm{Na}$ Ayuthaya, Professor Shōji Sasamoto, Ms Haruka Yoshida, Mr Hong Klatalae, Mr Kevin Macdonald, Ms Thein Thein Win, and Mr Yũichi Konno for their kind assistance with data collection. I also thank the anonymous reviewers for their helpful comments on the manuscript.

Dr Senjo Nakai teaches media and journalism at Thammasat University, Thailand. His current interests include the Asian mediascape, Japanese cinema, and the roles of tactical media in public health campaigns, natural disaster management and political communication. 